\title{
Can Sample Type Affect Vitamin D Concentration?
}

\author{
Anitha Devanath ${ }^{1}$, Jayakumari $\mathrm{S}^{2}$, Shubha N Prakash ${ }^{3}$, Reshma Raghu ${ }^{4}$
}

\begin{abstract}
Aim and objectives: To compare and evaluate the effect of sample type on vitamin D concentration in order to avoid multiple sample collection. Materials and methods: The study was conducted in a tertiary care hospital on 40 adult subjects whose samples were for both serum vitamin $D$ and plasma parathyroid hormone (PTH). Leftover plasma sample was utilized for vitamin D analysis. Samples were analyzed on Advia Centaur XP from Siemens Healthineers. Bland-Altman analysis and regression equation were derived to evaluate the extent of agreement and conversion between sample types.

Results and conclusion: Serum vitamin D is higher than plasma vitamin D (by $6.5 \mathrm{ng} / \mathrm{mL}$ ), and it is more pronounced in samples with vitamin D greater than $20 \mathrm{ng} / \mathrm{mL}$.

Clinical significance: It is important that lab and clinicians should be aware of the comparably large preanalytical bias introduced by changing between serum and EDTA plasma sample for vitamin D analysis. This would impact patients who are serially monitored for vitamin D supplementation.

Keywords: Plasma vitamin D, Serum vitamin D, Total change limit.

Indian Journal of Medical Biochemistry (2020): 10.5005/jp-journals-10054-0129
\end{abstract}

\section{INTRODUCTION}

Measurement of 25-hydroxyvitamin D reflects the vitamin D status of an individual. It is an important investigation for pathologies of bone and mineral metabolism. Vitamin D has been associated with a role in chronic diseases such as autoimmune, cardiovascular, infectious diseases, and cancers. ${ }^{1-3}$ It is important to monitor the vitamin $\mathrm{D}$ levels to evaluate the status and response to vitamin $\mathrm{D}$ supplements. Type of sample used for evaluating vitamin $D$ is of utmost importance in screening and serial monitoring.

Most often, vitamin D and parathyroid hormone (PTH) are estimated in the patient to understand the vitamin D status. The preferred sample type for vitamin $D$ in majority of immunoassay platforms is serum, and the preferred sample type for PTH is plasma. Hence, the two types of samples were collected from each subject for vitamin D and PTH analyzes. To eliminate the two different sample collection tubes, we decided to compare and evaluate the sample type (serum and plasma) on vitamin D concentration. In our study, we hypothesized that there is no difference in vitamin $D$ values between serum and plasma samples.

\section{Materials and Methods}

Forty adult subjects were selected for evaluating the serum vitamin D and plasma (EDTA) PTH since both the samples were drawn for each subject. Serum and plasma were separated after centrifugation. Hemolyzed, icteric, lipemic, and samples with insufficient volume were excluded. Leftover plasma sample after PTH analysis was utilized for plasma vitamin D analysis. Vitamin D in serum and plasma was analyzed by chemilumniscence in Advia Centaur XP automated immunoassay analyzer from Siemens Healthcare Pvt. Ltd. Biorad quality control material was used to validate the analytical runs. Study population was represented using descriptive statistics. Bland-Altman analysis was done to evaluate the extent of agreement. A regression equation was derived to explore the option of calculating the vitamin $D$ values for serum from plasma.
${ }^{1-3}$ Department of Biochemistry, St Johns Medical College, Bengaluru, Karnataka, India

${ }^{4}$ Department of Biochemistry, Cytecare Hospitals, Bengaluru, Karnataka, India

Corresponding Author: Anitha Devanath, Department of Biochemistry, St Johns Medical College, Bengaluru, Karnataka, India, Phone: +91 9900144602, e-mail: anithadevanath@yahoo.co.in

How to cite this article: Devanath A, Jayakumari S, Prakash SN, et al. Can Sample Type Affect Vitamin D Concentration? Indian J Med Biochem 2020;24(1):16-18.

Source of support: Nil

Conflict of interest: None

\section{Results}

Forty samples selected (sample size was based on $\pm 10 \%$ effect size with a power of $80 \%$ and within $95 \%$ confidence interval) for analysis spanned across deficient $(<20 \mathrm{ng} / \mathrm{mL} ; n=18)$, insufficient (20-29 ng/mL; $n=10)$, and sufficient vitamin D concentration $(\geq 30 \mathrm{ng} / \mathrm{mL} ; n=12$ ). Categorization of vitamin D status was based on published studies, ${ }^{4,5}$ though there are varied reports that are based on the cutoff value of the western population, i.e., $>20 \mathrm{ng} / \mathrm{mL}$ being deemed sufficient. ${ }^{6}$ Serum vitamin D ranged from 5.43 to $39.3 \mathrm{ng} / \mathrm{mL}$ and was found to be higher than plasma (EDTA) vitamin D by $6.51 \mathrm{ng} / \mathrm{mL}$ (Table 1). The extent of agreement between serum and plasma vitamin $\mathrm{D}$ is depicted in Figure 1. Regression analysis was done between serum and plasma vitamin $D$ samples. There was a good correlation of 0.889 and regression equation is $y=0.805$ $x-2.7955$, with $x$ and $y$ being the serum and plasma vitamin $D$, respectively (Fig. 2).

\section{Discussion}

The prevalence of vitamin D deficiency is $70-100 \%$ in Indian population ${ }^{7}$ which is associated with a multitude of diseases.

(C) The Author(s). 2020 Open Access This article is distributed under the terms of the Creative Commons Attribution 4.0 International License (https://creativecommons. org/licenses/by-nc/4.0/), which permits unrestricted use, distribution, and non-commercial reproduction in any medium, provided you give appropriate credit to the original author(s) and the source, provide a link to the Creative Commons license, and indicate if changes were made. The Creative Commons Public Domain Dedication waiver (http://creativecommons.org/publicdomain/zero/1.0/) applies to the data made available in this article, unless otherwise stated. 
Table 1: Comparison of vitamin D concentration in serum and plasma

\begin{tabular}{|c|c|c|c|c|}
\hline Serum vs plasma EDTA & $\begin{array}{l}\text { Vitamin } D(n g / m L) \text { (overall) } \\
(n=40), \text { mean } \pm S D\end{array}$ & $\begin{array}{l}\text { Vitamin } D \text { deficient } \\
(<20 \mathrm{ng} / \mathrm{mL})(n=18), \\
\text { mean } \pm S D\end{array}$ & $\begin{array}{l}\text { Vitamin D insufficient } \\
(21-29 \mathrm{ng} / \mathrm{mL})(n=10) \\
\text { mean } \pm S D\end{array}$ & $\begin{array}{l}\text { Vitamin D sufficient } \\
(\geq 30 \mathrm{ng} / \mathrm{mL}) \\
(n=12), \text { mean } \pm S D\end{array}$ \\
\hline Serum & $19.12 \pm 8.49$ & $13.14 \pm 3.86$ & $23.92 \pm 2.94$ & $32.96 \pm 3.91$ \\
\hline Plasma & $12.61 \pm 7.25$ & $7.38 \pm 2.99$ & $17.48 \pm 2.63$ & $23.61 \pm 4.75$ \\
\hline Avg. mean difference & $6.51 \pm 2.93$ & $3.57 \pm 3.67$ & $1.72 \pm 3.11$ & $1.56 \pm 3.62$ \\
\hline
\end{tabular}

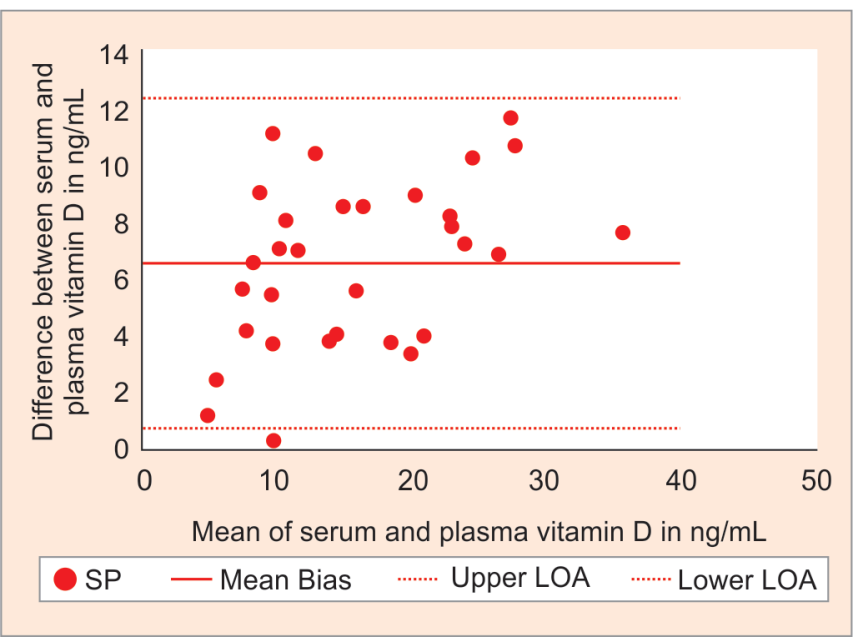

Fig. 1: Agreement between serum and plasma vitamin D. S, serum; $P$, plasma; LOA, limit of agreement

The immunoassay platforms prefer serum as the sample, though plasma can also be used. The biological reference interval used for screening vitamin D status is based on serum levels. Our findings show that the plasma EDTA samples are lower than serum vitamin D by $6.51 \mathrm{ng} / \mathrm{mL}$, unlike few published studies. Yu et al. ${ }^{8}$ showed that EDTA plasma and serum vitamin D samples did not show any difference. However, they did observe that heparinized plasma vitamin $\mathrm{D}(n=20)$ was significantly higher than serum vitamin $\mathrm{D}$ especially in samples with delayed centrifugation of 96 hours, and it was inferred that it is not of physiological significance. Colak et al. ${ }^{9}$ have reported that there is no significant difference in serum and plasma vitamin $\mathrm{D}(n=15)$ which have been centrifuged at both

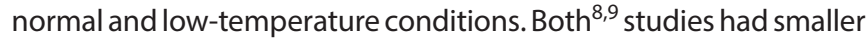
sample size in comparison to our study.

There is a possibility that plasma samples have lower values in comparison to serum due to dilution. This can be explained by the osmotic effect of the anticoagulant that could have resulted in redistribution of fluids from erythrocytes to outside, thereby contributing to dilution. In our study, a wide variability was observed with plasma sample, and this difference in vitamin D values between the sample type is more prominent in patients with vitamin D levels $>20 \mathrm{ng} / \mathrm{mL}$ (insufficiency and sufficiency). The variability in plasma values cannot be entirely explained by the dilutional effect due to anticoagulants.

It is very difficult to ascertain whether this variability is due to the analytical issues ${ }^{10}$ or the sample type used. In an attempt to differentiate between analytical variability and sample type difference, the total change limit (TCL) was calculated. The TCL is determined as a combination of analytical and intraindividual imprecision. $^{11}$

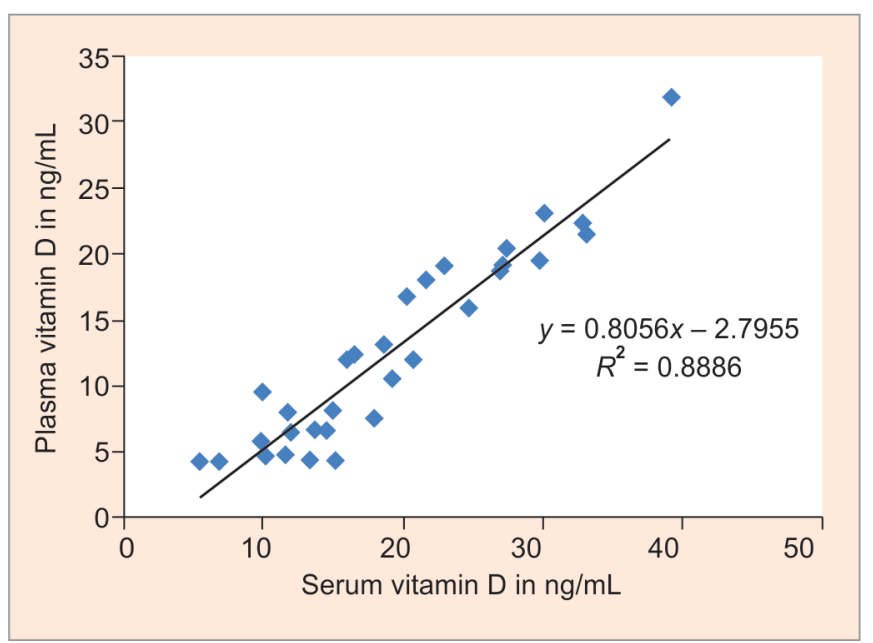

Fig. 2: Correlation between serum and plasma vitamin $D$ concentration

$$
\text { Total change limit }=\operatorname{Sqrt}\left[\left(0.277 * \mathrm{CV}_{\mathrm{a}}\right)^{2}+\left(0.5 * \mathrm{CV}_{\mathrm{b}}\right)^{2}\right]
$$

where $\mathrm{CV}_{\mathrm{a}}$ is the analytical imprecision of the lab (8.68\%) and $\mathrm{CV}_{\mathrm{b}}$ is the within-subject or intra-assay imprecision (8.8\%) obtained from the published data. ${ }^{12}$ The calculation of TCL can vary widely and is dependent on the source ${ }^{13}$ of imprecision data for intra-assay, and we have chosen the recent published data.

The TCL for vitamin D was calculated as $5.01 \%$ for method performance in our lab. In our study, serum and plasma vitamin D mean values (overall) were 19.12 and $12.60 \mathrm{ng} / \mathrm{mL}$, respectively. The difference obtained was $34.1 \%$, and beyond TCL of $5.01 \%$, it is indicative of the difference between sample types as significant and not entirely due to method variability. When we calculate the percentage difference in vitamin D insufficient (21-29 $\mathrm{ng} / \mathrm{mL})$ and sufficient ( $\geq 30 \mathrm{ng} / \mathrm{mL}$ ) subjects, there was difference of 26.9 and $28.4 \%$, respectively in comparison to $43.8 \%$ difference as seen in vitamin D-deficient ( $\leq 20 \mathrm{ng} / \mathrm{mL}$ ) subjects.

If serum is the preferred sample, there is a possibility of missing out on diagnosing vitamin D deficiency and/or insufficiency and alternatively with plasma vitamin D levels, we could be adding noise to the prevalent vitamin $D$ deficiency. Plasma sample would be a preferable choice to assess vitamin $D$ status because it is beneficial to err on the side of vitamin $\mathrm{D}$ supplementation.

\section{Conclusion}

Plasma would be a preferred sample type to evaluate vitamin $D$ status, though there is significant variability between serum and plasma vitamin $D$ values, with serum values being higher by $6.51 \mathrm{ng} / \mathrm{mL}$. 


\section{Clinical Significance}

It is important that lab and clinicians should be aware of the comparably large preanalytical bias introduced by changing between serum and EDTA plasma samples for vitamin D analysis. This would impact patients who are serially monitored for vitamin D supplementation.

\section{Ethical Approval}

All procedures performed in our study involving human participants were in accordance with the ethical standards of the institutional and/or national research committee and with the 1964 Helsinki declaration and its later amendments or comparable ethical standards. In our study, the leftover (or remaining) sample that was meant for discarding was used for the additional analysis. No additional samples were drawn from patients, and all investigations carried out formed a part of the standard of care.

\section{Acknowledgment}

We would like to acknowledge technical and application support by Siemens Healthineers to carry out this project.

\section{References}

1. Van Schoor NM, Lips P. Worldwide vitamin D status. Best Pract Res Clin Endocrinol Metab 2011;25(4):671-680. DOI: 10.1016/ j.beem.2011.06.007.

2. Mithal A, Wahl DA, Bonjour JP, et al. Global vitamin D status and determinants of hypovitaminosis D. Osteoporos Int 2009;20(11): 1807-1820. DOI: 10.1007/s00198-009-0954-6.

3. Van der Meer IM, Middelkoop BJ, Boeke AJ, et al. Prevalence of vitamin D deficiency among Turkish, Moroccan, Indian and Sub-Sahara African populations in Europe and their countries of origin: an overview. Osteoporos Int 2011;22(4):1009-1021. DOI: 10.1007/s00198-010-1279-1.
4. Ramakrishnan S, Bhansali A, Bhadada SK, et al. Vitamin D status and its seasonal variability in healthy young adults in an asian indian urban population. Endocr Pract 2011;17(2):185-191. DOI: 10.4158/EP10155. OR.

5. Marwaha RK, Tandon N, Garg MK, et al. Vitamin D status in healthy indians aged 50 years and above. J Assoc Physicians India 2011;59:706-709.

6. Institute of medicine (US) committee to review dietary reference intakes for vitamin D and calcium. In: Ross AC, Taylor CL, Yaktine AL. Dietary Reference Intakes for calcium and vitamin D. Washington (DC): National Academic Press (US); 2011. Available from: https:// www.ncbi.nlm.nih.gov/books/NBK56070/doi:10.17226/13050.

7. Ritu G, Gupta A. Vitamin D deficiency in India: prevalence, causalities and interventions. Nutrients 2014;6(2):729-775. DOI: 10.3390/ nu6020729.

8. Yu CL, Falk RT, Kimlin MG, et al. The impact of delayed blood centrifuging, choice of collection tube and type of assay on 25-hydroxyvitamin D concentration. Cancer Causes Control 2010;21(4):643-648. DOI: 10.1007/s10552-009-9485-x.

9. Colak A, Toprak B, Dogan N, et al. Effect of sample type, centrifugation and storage conditions on vitamin D concentration. Biochemica Medica 2013;23(3):321-325. DOI: 10.11613/BM.2013.039.

10. Holmes EW, Garbincius J, McKenna KM. Analytical variability among methods for the measurement of 25-hydroxyvitamin D. Still adding to the noise. Am J Clin Pathol 2013;140(4):550-560. DOI: 10.1309/ AJCPU2SKW1TFKSWY.

11. Oddoze C, Lombard E, Portugal H. Stability study of 81 analytes in human whole blood, in serum and in plasma. Clinical Biochemistry 2012;45(6):464-469. DOI: 10.1016/j.clinbiochem.2012.01.012.

12. Rezayi M, Ghayour-Mobarhan M, Sany SBT, et al. A comparison of analytical methods for measuring concentrations of 25-hydroxy vitamin D in biological samples. Anal Methods 2018;10:5599-5612. DOI: 10.1039/C8AY02146E.

13. Ricos C, Alvarez V, Cava F, et al. Current databases on biologic variation:pros, cons and progress. Scand J Clin Lab Invest 1999;59(7):491-500. DOI: 10.1080/00365519950185229. 